\title{
Effects of water temperature changes on the endogenous and exogenous rhythms of oxygen consumption in glass eels Anguilla japonica
}

\author{
Wan Soo Kim ${ }^{1}$, Seong Jin Yoon ${ }^{1}$, Hyung Tae Moon ${ }^{2}$, Tae Won Lee ${ }^{2, *}$ \\ ${ }^{1}$ Marine Environment and Climate Change Laboratory, Korea Ocean Research and Development Institute, Ansan, PO Box \\ 29, Seoul 425-600, South Korea \\ ${ }^{2}$ Department of Oceanography, Chungnam National University, Taejon 305-764, South Korea
}

\begin{abstract}
The oxygen consumption rate (OCR) of glass eels Anguilla japonica was measured to determine the effects of water temperature changes on their endogenous and exogenous rhythms. Glass eels were exposed to different water-temperature patterns during simulated 12, 14 and $24 \mathrm{~h}$ cycles. The OCR of wild glass eels, freshly collected from estuaries, exhibited a clear endogenous circatidal rhythm while kept in constant darkness at $15 \pm 0.1^{\circ} \mathrm{C}$. However, if the temperature was varied, the glass eels OCR coincided with the gradually increasing water temperature $\left(\Delta t=1^{\circ} \mathrm{C}\right.$ per 12 or $24 \mathrm{~h})$ in the experimental chamber. This minor variation in water temperature $\left(\Delta t=1^{\circ} \mathrm{C}\right.$ per 12 or $24 \mathrm{~h}$ ) was significant enough to affect the rhythmicity of the glass eels' OCR. When the glass eels were exposed to a cyclic increase or decrease in water temperature $\left(1^{\circ} \mathrm{C}\right.$ per $\left.14 \mathrm{~h}\right)$, the OCR peaks displayed a clear rhythmicity at $14 \mathrm{~h}$ intervals. The results indicate that the glass eels' OCR is controlled not only by an endogenous circatidal rhythm, but also by exogenous rhythms related to small environmental changes, such as water temperature changes of as little as $1^{\circ} \mathrm{C}$. The possible mechanisms underlying these temperature responses are discussed and the implications of the findings for the eco-physiology and metabolic activity rhythms of glass eels are highlighted.
\end{abstract}

KEY WORDS: Glass eel · Anguilla japonica · Oxygen consumption · Temperature - Rhythm · Endogenous $\cdot$ Exogenous

\section{INTRODUCTION}

The Japanese eel Anguilla japonica spawns just south of the salinity front in the North Equatorial Current in the NW Pacific Ocean (Tsukamoto 1992). The eel larvae, called leptocephali, drift from the spawning area in the warm North Equatorial Current and then enter the Kuroshio Current. The fully grown leptocephali metamorphose into glass eels in the Kuroshio waters near Okinawa and Taiwan. The glass eels migrate over the continental shelf and enter into the estuaries of the region. During this migration, the eels

*Corresponding author. Email: twlee@cnu.ac.kr encounter different water conditions and very likely respond by varying their physiology.

The leptocephali migrate vertically during their drift in the open ocean (Kajihara et al. 1988, Otake et al. 1998). During this time, the metabolic activities of the larvae may display a circadian rhythm caused by the diurnal vertical migration. Glass eels, migrating over a continental shelf into rivers from the open ocean, experience different water temperatures as well as different water chemistries (i.e. seawater, brackish water and fresh water), in which their metabolic activity changes. The physiological processes of the glass eels in the estuaries should be defined by the potential 'Zeitgeber' for circatidal rhythms through mechanical agitation, temperature, salinity and tidal hydrostatic pressure. As the glass eels move from the estuaries into the 
rivers, their physiological processes should again change from a $12.4 \mathrm{~h}$ pattern (circatidal) defined by the tide to a $24 \mathrm{~h}$ pattern (circadian), because, in the rivers, the free-running periods exceed the tidal periods. Therefore, exposure of glass eels to sudden changes in environmental conditions may severely affect their physiological processes. In addition to changes in the rhythmic activities of the eels during migration, they live in different temperature regimes. The leptocephali migrate in warm waters, such as the North Equatorial Current and the Kuroshio Current, but after metamorphosis, the glass eels migrate over the continental shelf and enter the local rivers during the cold months (Lee et al. 2001).

Many researchers have reported that most marine fish exhibit rhythms of $12.4 \mathrm{~h}$ in their behavior and metabolic process, coinciding with the rise and fall of tides, i.e. tidal rhythms (Northcott et al. 1990, 1991, Gibson 1992, Leatherland et al. 1992). It is not surprising, therefore, that a number of these organisms have endogenous circatidal rhythms of behavior, physiology and reproduction (Taylor 1984). Gibson (1984) reported 16 fish species that exhibit a rhythmic activity with a period similar to the $12.4 \mathrm{~h}$ period of the tidal cycle. However, most of these species are found in the inshore water. American glass eels Anguilla rostrata collected during their upstream migration exhibited a rhythmic activity with circatidal periodicity when groups of them were tested in the presence of water currents under constant laboratory conditions (Wippelhauser \& McCleave 1988). However, few data are available on the relationship between water temperature changes and metabolic activity rhythms in eels.

The present study aimed to demonstrate the importance of internal timing for understanding certain aspects of field studies. Therefore, the study investigated whether a circatidal rhythm of oxygen consump- tion exists in wild glass eels collected in estuaries. In addition, we determined the effects of water temperature changes on the respiration of glass eels when exposed to different temperature patterns during simulated 12, 14 and $24 \mathrm{~h}$ cycles.

\section{MATERIALS AND METHODS}

Glass eels Anguilla japonica were collected from the Seogwipo estuary $\left(32 \mathrm{psu}^{\circ} 13^{\circ} \mathrm{C}\right)$ at the southern tip of Korea on 23 February 2001 and from the Kanghwa estuary $\left(20 \mathrm{psu}_{i} 15^{\circ} \mathrm{C}\right)$ on the western Korean coast on 24 May 2001. Wild glass eels were obtained from the estuaries during the flood tide using a dip net at night. Ninety eels were collected and had a mean length of $5.7 \pm 0.3 \mathrm{~cm}$ and wet weight $(\mathrm{WW})$ of $0.19 \pm 0.04 \mathrm{~g}$. The glass eels were immediately transported to the KORDI (Korea Ocean Research and Development Institute) laboratories. Before the experiments began, the eels were kept in a 201 holding tank in a BOD incubator (30A14, Revco) at a constant temperature in the dark without food for $12 \mathrm{~d}$. The temperature and salinity were kept close to the conditions in the glass eels' natural environment.

The oxygen consumption rate (OCR) of the glass eels was measured with an automatic intermittent-flowrespirometer (AIFR: 1 system with 2 chambers), similar to that previously described by Kim et al. (1996).

The experiments were carried out under 4 different temperature regimes (Table 1). In Expt 1, the glass eels were exposed to a $15^{\circ} \mathrm{C}$ constant temperature and the endogenous rhythm observed in 4 replicate experiments of varying duration (272.1 to 331.0 h). In Expt 2, the eels were subjected to a gradual temperature increase from 13 to $29^{\circ} \mathrm{C}$ by $1^{\circ} \mathrm{C} 24 \mathrm{~h}^{-1}$ and their OCR was measured in the 5 replicate experiments of vary-

Table 1. Anguilla japonica. Experiments to measure the oxygen consumption rate (OCR) of the fasted glass eels in the different temperature regimes. The OCR $\left(\mathrm{ml} \mathrm{O}_{2} \mathrm{~g}^{-1} \mathrm{WW} \mathrm{h}^{-1}\right)$ was measured in constant darkness. Glass eels $(\mathrm{n}=90)$ measured $5.7 \pm 0.3 \mathrm{~cm}$ (mean $\pm \mathrm{SD}$ ) in total length and $0.19 \pm 0.04 \mathrm{~g}$ in wet weight. Statistical values were computed for each batch from the 5163 to 12720 data points measured

\begin{tabular}{|c|c|c|c|c|}
\hline & $\begin{array}{l}\text { Wild glass eels } \\
\text { (at constant } \\
\text { temperature) }\end{array}$ & $\begin{array}{c}\text { Exposure to } \\
\text { temperature } \\
\text { changes of } \\
\Delta t=1^{\circ} \mathrm{C} 24 \mathrm{~h}^{-1}\end{array}$ & $\begin{array}{c}\text { Exposure to } \\
\text { temperature } \\
\text { changes of } \\
\Delta t=1^{\circ} \mathrm{C} 12 \mathrm{~h}^{-1}\end{array}$ & $\begin{array}{c}\text { Exposure to repeated } \\
\text { increases or decreases } \\
\text { in water temperature } \\
\left(1 \text { or } 2^{\circ} \mathrm{C} 14 \mathrm{~h}^{-1}\right)\end{array}$ \\
\hline Temperature $\left({ }^{\circ} \mathrm{C}\right)$ & 15 & $13-29$ & $14-28$ & $19-21$ \\
\hline Salinity (psu) & 20 & 20 & 20 & 20 \\
\hline Oxygen saturation level (\%) & $94.9-85.2$ & $94.9-85.3$ & $94.8-85.3$ & $94.9-85.1$ \\
\hline Flow rate $\left(\mathrm{ml} \mathrm{min}^{-1}\right)$ & 340 & 340 & 340 & 340 \\
\hline Duration (h) of the experiments & $272.1-331.0$ & $288.5-401.0$ & $260.1-361.0$ & $208.6-377.8$ \\
\hline Number of points measured & $6749-9539$ & $7251-8266$ & $7725-8841$ & $5163-12720$ \\
\hline Number of experiments & 4 & 5 & 5 & 4 \\
\hline Number of glass eels in each experiment & 5 & 5 & 5 & 5 \\
\hline
\end{tabular}


ing duration (288.5 to $401.0 \mathrm{~h}$ ). In Expt 3, the temperature increased by $1^{\circ} \mathrm{C} 12 \mathrm{~h}^{-1}$ and their OCR was measured from 14 to $28^{\circ} \mathrm{C}$ in the 5 replicate experiments of varying duration (260.1 to $361.0 \mathrm{~h}$ ). A temperature increase every 12 or $24 \mathrm{~h}$ may coincide with the tidal or the diurnal cycle, and therefore, Expt 4 was done using a $14 \mathrm{~h}$ period, which is not a common divisor of 12 or $24 \mathrm{~h}$ periodicity (e.g. 3, 4, 6, $24 \mathrm{~h}$ ). In the 5 replicate experiments, the temperature was increased and decreased by $1^{\circ} \mathrm{C}$ every $14 \mathrm{~h}$ for ca. $125 \mathrm{~h}$ and then by $2^{\circ} \mathrm{C}$ every $14 \mathrm{~h}$ for ca. $140 \mathrm{~h}$, in order to observe the effect of alternative change of temperature.

The initial temperature and salinity in the experiments were kept as closely as possible to those of the estuary environment. Two Plexglass respirometers (volume $=0.3 \mathrm{l}$ ) and an intermittent flow system were used simultaneously in a $30 \mathrm{l}$ tank. This allowed 5 glass eels to be monitored at the same time in 1 chamber. The water used in the experiments was filtered through sterile membrane filters (2 Saritorius capsule filters of $0.2 \mu \mathrm{m}$ input and $0.07 \mu \mathrm{m}$ output) to remove all

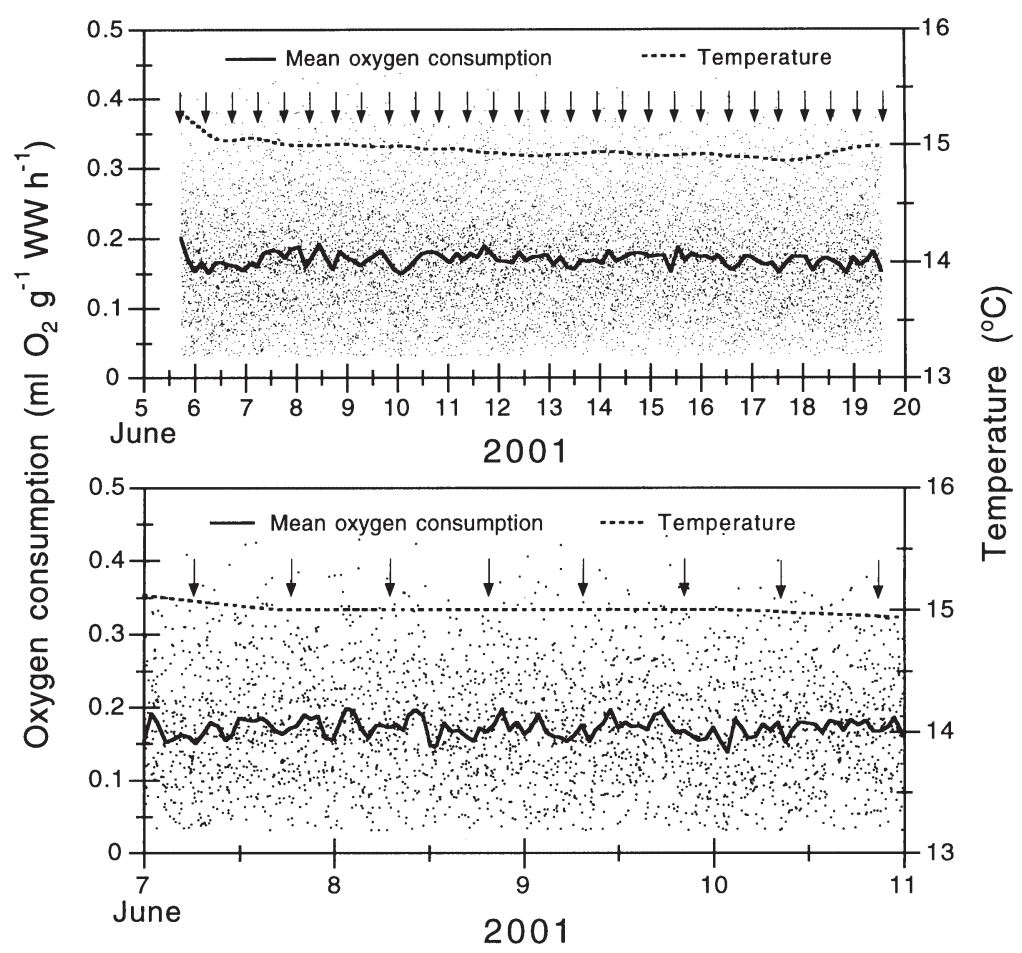

Fig. 1. Anguilla japonica. Upper panel: Time series of the oxygen consumption rate (OCR: $\mathrm{mlO}_{2} \mathrm{~g}^{-1} \mathrm{WW} \mathrm{h}^{-1}$ ) of groups of 5 fasted glass eels over a $331.0 \mathrm{~h}$ period. The experiments were conducted in constant darkness at $15 \pm 0.1^{\circ} \mathrm{C}$ and at oxygen saturation levels of 85.4 to $94.7 \%$. Mean OCR curves through the center of the data used a weighted smooth curve of $2 \%$. Data points represent mean OCR at $90 \mathrm{~s}$ intervals. Arrows indicate scheduled times of high tide at the location where the glass eels were collected. Lower panel: Enlargement of region from the upper panel, showing data from the 7 to 11 June 2001 experiment bacteria. The experiments were conducted in a dark incubator (RI-50-1060, Revco). The glass eels were not fed during the initial holding period or during the experiments in order to exclude the effects of feeding and digestion on oxygen consumption. A small fraction of water $\left(350 \mathrm{ml} \mathrm{min}^{-1}\right)$ was continuously circulated using a magnetic drive gear pump (Reglo-ZS, Ismatec Sa). All glass eels used for this study survived after the tests. Further details of the calculation methods and of the apparatus are given in Kim et al. $(1996,2001)$.

The OCR rhythm was determined with a maximum entropy spectral analysis (MESA) program using raw data transformed into 20 to 40 min lag intervals. The data were analyzed for periodicity using the techniques outlined by Dowse \& Ringo (1989). Analyses of OCR rhythms were performed using a $2 \%$ weighted smooth curve procedure. To plot a best-fit smooth curve through the center of the data, the locally weighted least-squares error method was used (KaleidaGraphy custom program for Macintosh, Synergy Software). The value of $2 \%$, obtained from repeated tests, showed the best-fit curve (Kim et al. 1999, 2001). Statistical values were computed for each batch from the data points measured. Values presented in this study are mean $\pm \mathrm{SD}$.

\section{RESULTS}

\section{Freshly collected wild glass eels from estuary}

Similar patterns of circatidal rhythmicity were observed for the freshly collected wild glass eels at constant darkness and temperature $\left(15.0 \pm 0.1^{\circ} \mathrm{C}\right)$ during all 4 experiments of varying duration ( 272.1 to $331.0 \mathrm{~h}$ ). The OCR of the glass eels measured in the $331.0 \mathrm{~h}$ experiment is shown in Fig. 1. The observed OCRs were highly variable, ranging from 0.03 to $0.44 \mathrm{ml} \mathrm{O}_{2}$ $\mathrm{g}^{-1} \mathrm{WW} \mathrm{h} \mathrm{h}^{-1}$. OCRs of fasted glass eels $(\mathrm{n}=5)$ were fitted to a weighted smooth curve of $2 \%$. The mean (mOCR), averaged over the duration of the experiment and the range of oxygen levels $\left(85.2\right.$ to $94.7 \%$ ), was $0.17 \pm 0.076 \mathrm{mlO}_{2}$ $\mathrm{g}^{-1} \mathrm{WW} \mathrm{h}^{-1}$. The OCR peaks did not correspond with the high tides (Fig. 1). Rather, the OCR peaks lagged slightly (up to 3 to $4 \mathrm{~h}$ ) behind the times of the high tides at the collection site (Fig. 1, lower panel).

A MESA plot of the data presented in Fig. 1 is shown in Fig. 2. The OCR peaks during the $13.8 \mathrm{~d}$ experiment mainly occurred at $12.5 \mathrm{~h}$ intervals, corresponding with a circatidal rhythm. In addition, the OCR also showed minor peaks in short intervals of $8.6 \mathrm{~h}$. 


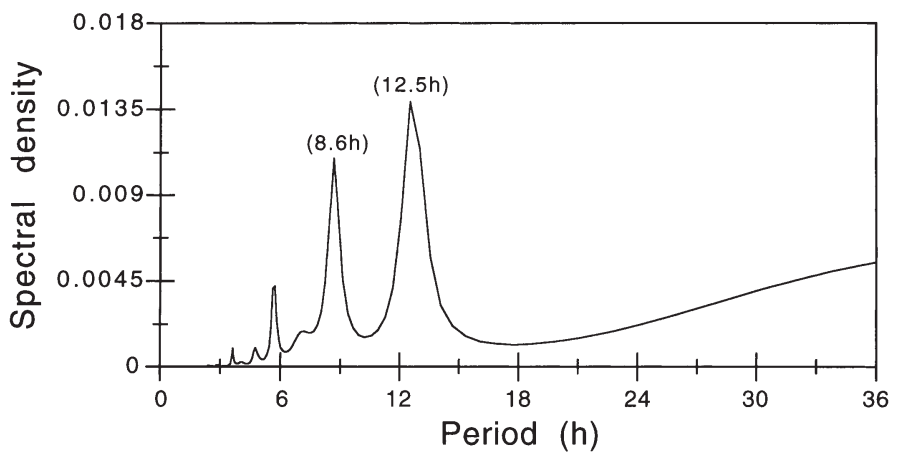

Fig. 2. Anguilla japonica. Maximum entropy spectral analysis (MESA) spectra from data presented in Fig. 1. Period lengths (h) corresponding to the dominant peaks in the MESA plots are given in parentheses

\section{Exposure to temperature changes during simulated 24 h cycles}

The 5 replicate experiments of varying duration (288.5 to $401.0 \mathrm{~h}$ ) also gave a similar result. The OCR for groups of 5 fasted glass eels observed during a $377.8 \mathrm{~h}$ experiment is depicted in Fig. 3 and fitted to a weighted smooth curve of $2 \%$. The OCR remained relatively constant during the first $48 \mathrm{~h}$ at $13^{\circ} \mathrm{C}$. About 15 cycles were observed during the $363.0 \mathrm{~h}$ (15.1 d) period and corresponded well with the results of the 15 temperature increases $(363.0 / 24=15.1$, see arrows in Fig. 3). However, the OCR patterns did not correspond with the temperature changes (Fig. 3, upper panel). Rather, the variation points of the OCR lagged ca. $3 \mathrm{~h}$ behind the timing of the temperature changes (Fig. 3, lower panel). MESA spectra of the data set (Fig. 3) indicated that OCR peaks mainly occurred at $23.9 \mathrm{~h}$ intervals (Fig. 4).

\section{Exposure to temperature changes during simulated 12 h cycles}

Five replicate experiments (duration of 260.1 to $361.0 \mathrm{~h}$ ) all gave results similar to those presented in Fig. 5. The OCRs showed a pronounced pattern and long time spans of rhythmicity with increasing water temperature and increased up to 22 to $23^{\circ} \mathrm{C}$. The magnitude of mOCR also coincided with the increasing temperature. The 8 OCR cycles corresponded with the results of the 8 temperature increases between 14 and $23^{\circ} \mathrm{C}$ over $98 \mathrm{~h}(98 / 12=8.2$, see arrows on Fig. 5, region a). As the temperature increased from 23 to $27.5^{\circ} \mathrm{C}$, the OCR decreased (Fig. 5, region b). The observed rhythm had about 6 cycles during the $70 \mathrm{~h}$ period. The OCR patterns did not correspond with the temperature changes (Fig. 5, upper panel). Rather, the variation points of the OCR lagged ca. 2 to $3 \mathrm{~h}$ behind the timing of the temperature changes (Fig. 5, lower panel). MESA plots corresponding to the data presented in Fig. 5 are shown in Fig. 6. The OCR peaks for the glass eels occurred at 12.2 and $12.5 \mathrm{~h}$ intervals, corresponding to the increasing rate water temperature $\left(\Delta t=1^{\circ} \mathrm{C} 12 \mathrm{~h}^{-1}\right)$. The instantaneous OCR also exhibited peaks at 24.1 and $24.2 \mathrm{~h}$ intervals.

\section{Exposure to alternative temperature changes during simulated $14 \mathrm{~h}$ cycles}

Among the 5 replicate experiments (duration of 208.6 to $377.8 \mathrm{~h}$ ) showing similar trends, the instantaneous OCR recorded for a period of $377.8 \mathrm{~h}$ is shown in Fig. 7. During the experiment, relatively high OCRs were observed during the initial phase of the measurements,

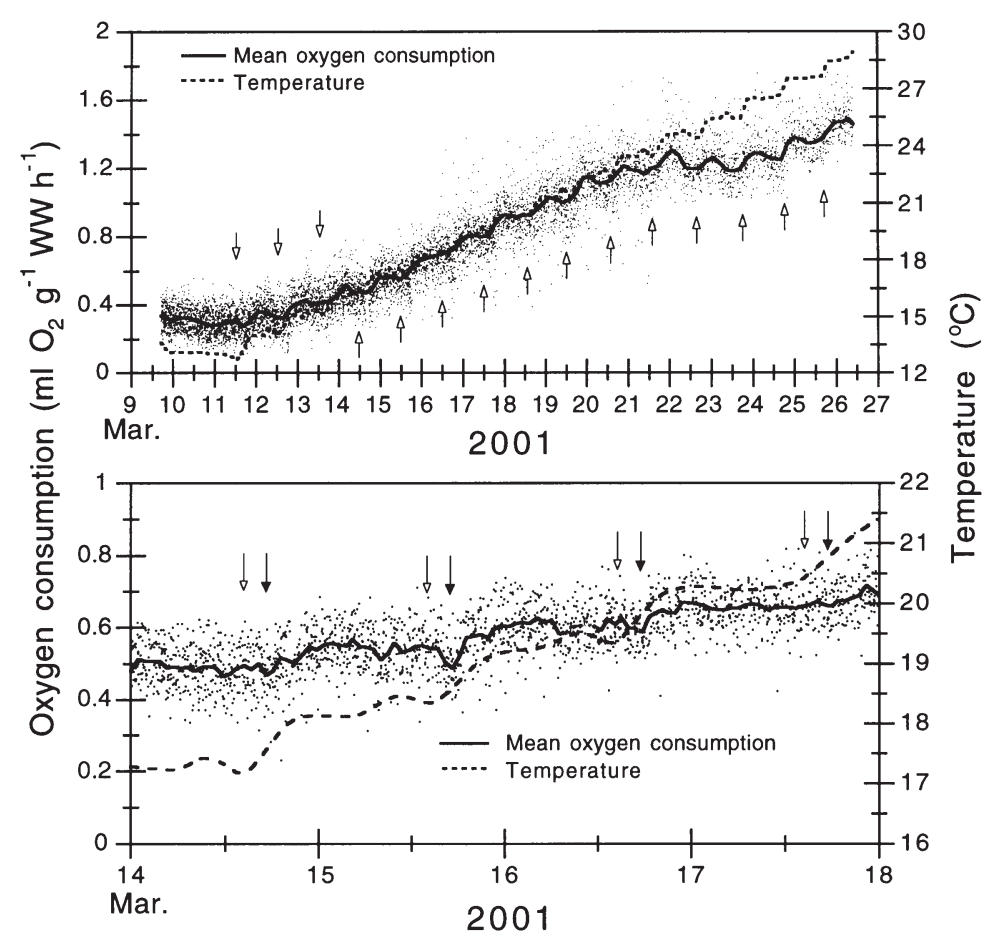

Fig. 3. Anguilla japonica. Upper panel: Patterns of oxygen consumption rate (OCR: $\mathrm{mlO}_{2} \mathrm{~g}^{-1} \mathrm{WW} \mathrm{h} \mathrm{h}^{-1}$ ) of groups of 5 fasted glass eels, which were subjected to temperature increases from 13 to $29^{\circ} \mathrm{C}$ during a $363.0 \mathrm{~h}$ $\left(\Delta t=1^{\circ} \mathrm{C} 24 \mathrm{~h}^{-1}\right)$. The open arrows indicate the timing of temperature changes. Arrows indicate scheduled times of high tide at the location where the glass eels were collected. Lower panel: Enlargement of region from the upper panel, showing data from the 14 to 18 March 2001 experiment. The open and dark arrows indicate peaks of OCR and temperature changes, respectively 
which lasted 3 to $4 \mathrm{~h}$. These fasted glass eels had a rhythmicity of about 9 cycles during the 9 alternative changes of temperature $\left(1^{\circ} \mathrm{C} 14 \mathrm{~h}^{-1}\right)$ for the $126 \mathrm{~h}$ experiment (Fig. 7, region a) and 10 cycles during the 10 alternative changes of temperature $\left(2^{\circ} \mathrm{C} 14 \mathrm{~h}^{-1}\right)$ for the $140 \mathrm{~h}$ experiment (Fig. 7, region b). The OCR amplitude for eels sub-

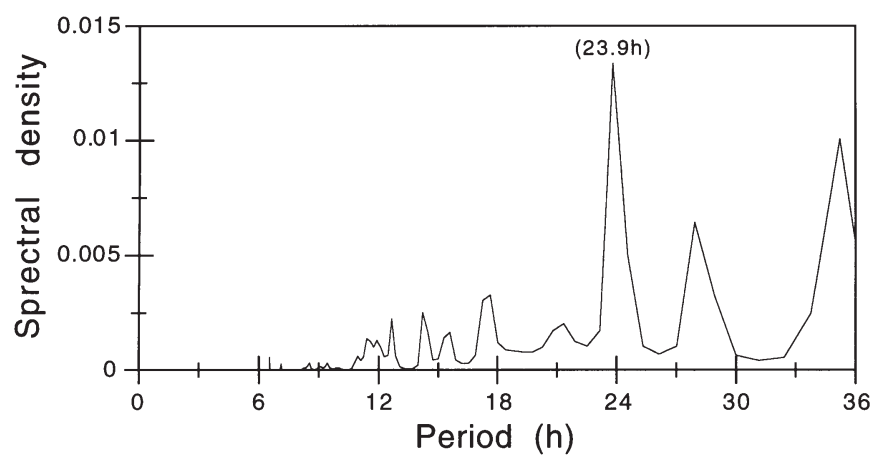

Fig. 4. Anguilla japonica. Maximum entropy spectral analysis (MESA) spectra from data presented in Fig. 3. The period length (h) corresponding to the dominant peak in the MESA plots is given in parentheses

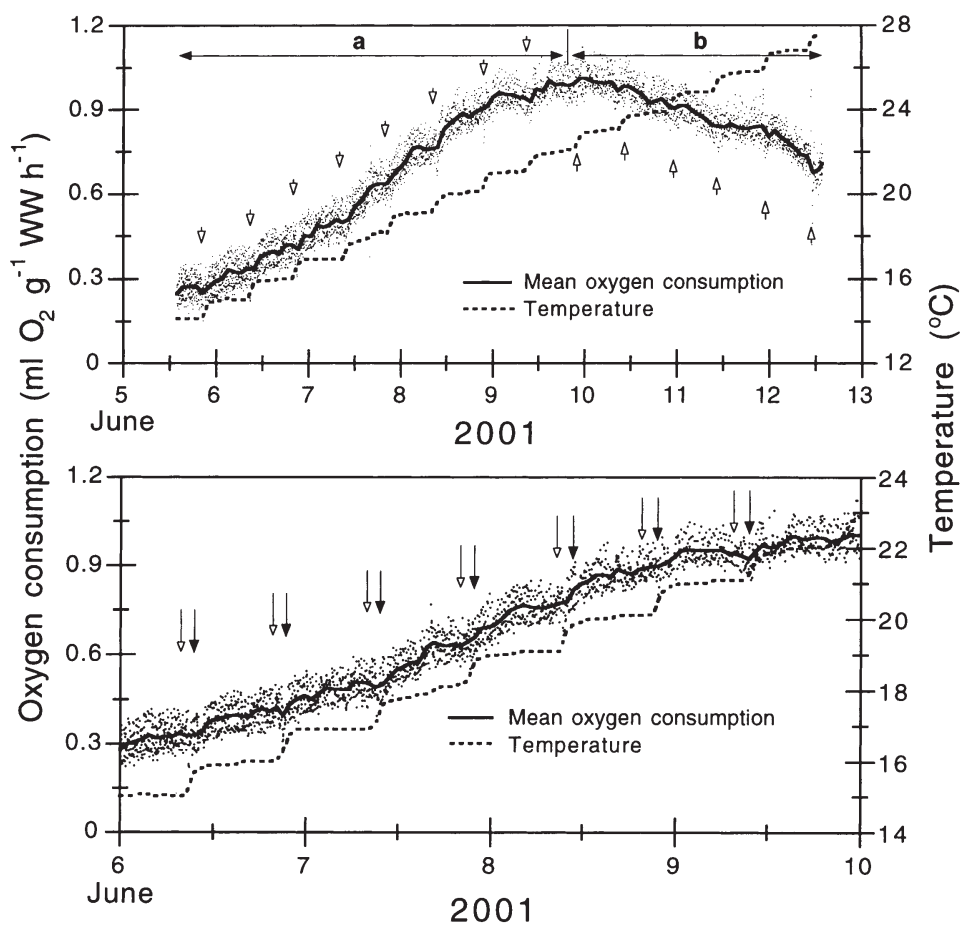

Fig. 5. Anguilla japonica. Patterns of oxygen consumption rate (OCR: $\mathrm{mlO}_{2} \mathrm{~g}^{-1} \mathrm{WW} \mathrm{h}{ }^{-1}$ ) of groups of 5 fasted glass eels, which were subjected to temperature increases from 14 to $27.5^{\circ} \mathrm{C}$ during a $228.1 \mathrm{~h}$ period $\left(\Delta t=1^{\circ} \mathrm{C} 12 \mathrm{~h}^{-1}\right)$. The open arrows indicate the timing of temperature changes. Information provided in regions $\mathrm{a}$ and $\mathrm{b}$ is from different OCR patterns exhibited by the eels during the experiments. Lower panel: Enlargement of region from the upper panel, showing data from the 6 to 10 June 2001 experiment. The open and dark arrows indicate peaks of OCR and temperature changes, respectively

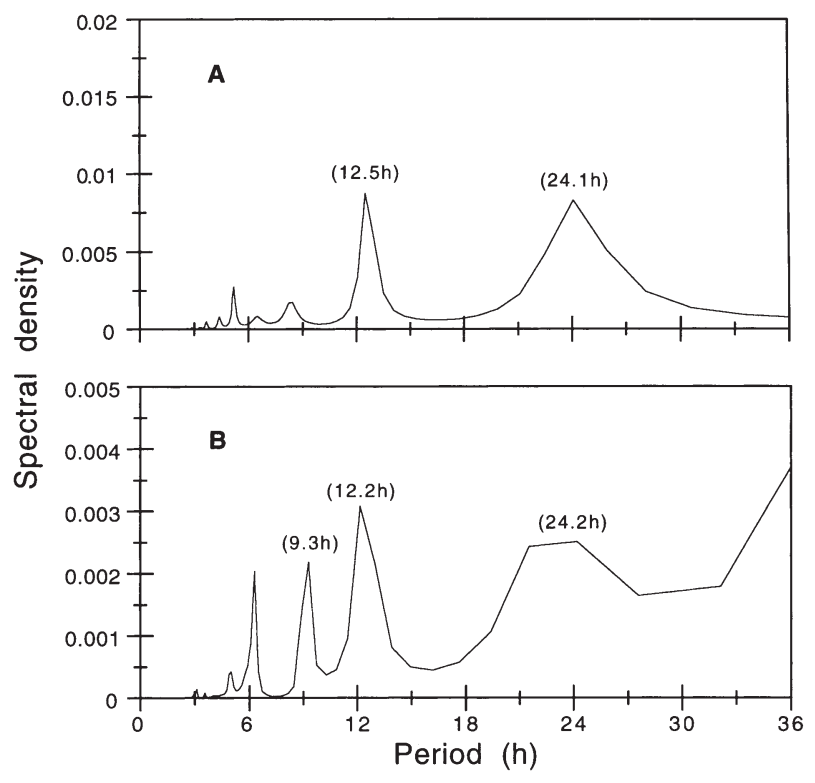

Fig. 6. Anguilla japonica. (A,B) Maximum entropy spectral analysis (MESA) spectra for data presented in Fig. 7 in regions a and $\mathrm{b}$. Period lengths $(\mathrm{h})$ corresponding to the dominant peaks in the MESA plots are given in parentheses

jected to a periodic change of $2^{\circ} \mathrm{C}$ was larger than for those subjected to a $1^{\circ} \mathrm{C}$ change. The OCR peaks did not correspond with the temperature changes (Fig. 7, upper panel). Rather, the OCR peaks lagged ca. $3 \mathrm{~h}$ behind the timing of the temperature changes (Fig. 7, lower panel). MESA spectra of the 2 data sets presented in Fig. 7 indicated that the OCR peak occurred at exactly $14 \mathrm{~h}$ intervals, corresponding to the $14 \mathrm{~h}$ exposure cycles (Fig. 8).

\section{DISCUSSION}

Tidal rhythms are present in nearly all groups of marine organisms (Enright 1975, Bünning 1977, Palmer 1995). There have been numerous examples of tidal-based rhythmic activities in intertidal fish (reviewed in Gibson 1984). However, Wippelhauser \& McCleave (1988) stated that it would be difficult to experimentally determine whether the activity of eels represents a free-running circatidal rhythm or a free-running circadian rhythm with a bimodal activity pattern. Most studies of tidal periodicity activity rhythms have been conducted for only a few days after sample collection, and were further hindered by inappropriate methodology and technical difficulties in determining oxygen consumption using conventional respirometers (Kim et al. 1996, 1999). 


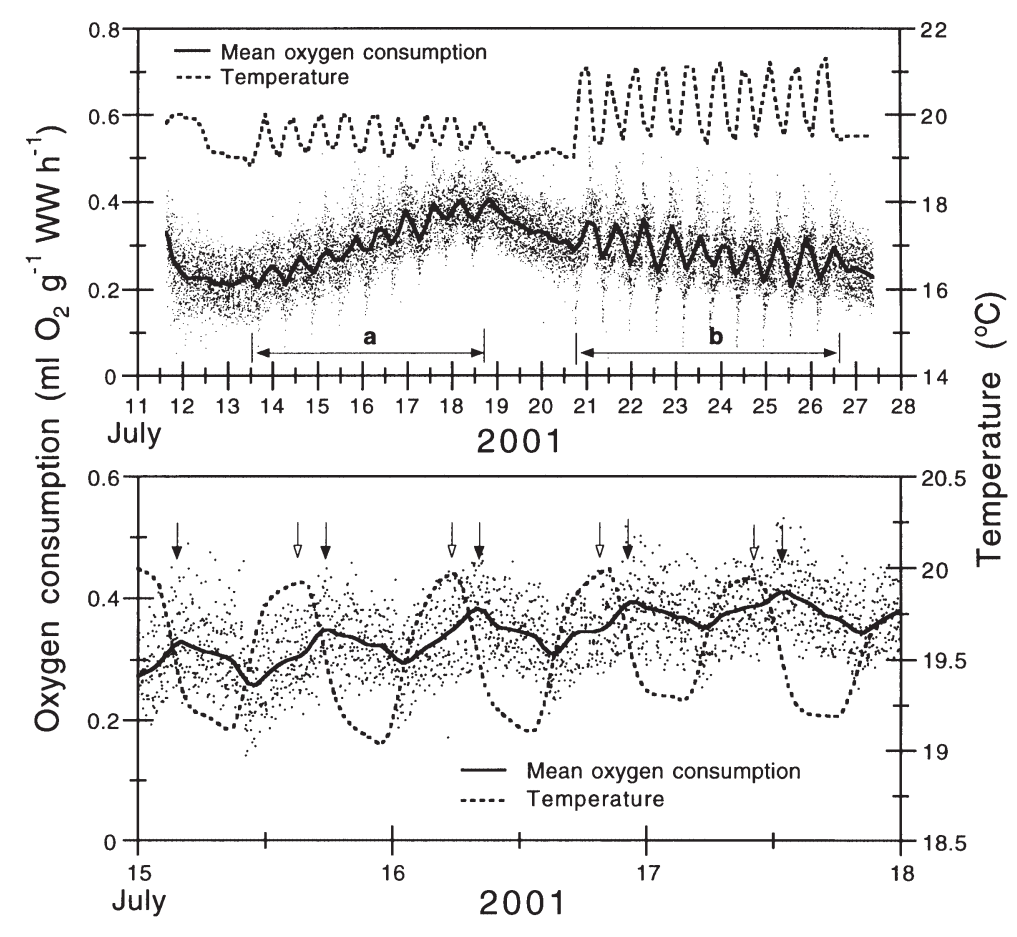

Fig. 7. Anguilla japonica. Upper panel: The oxygen consumption rate patterns (OCR: $\mathrm{mlO}_{2} \mathrm{~g}^{-1} \mathrm{WW} \mathrm{h} \mathrm{h}^{-1}$ ) of groups of 5 fasted glass eels over a $377.8 \mathrm{~h}(15.7 \mathrm{~d})$ period, during which they were subjected to temperature increases or decreases; region a: $1^{\circ} \mathrm{C} 14 \mathrm{~h}^{-1}$ and region b: $2^{\circ} \mathrm{C} 14 \mathrm{~h}^{-1}$ ). Lower panel: Enlargement of region a from the upper panel, showing data from the 15 to 18 July 2001 experiment. The open and dark arrows indicate peaks of OCR and temperature changes, respectively

In the present study, the glass eels collected in the estuary were isolated from any apparent variation in external stimuli, such as light, temperature, food, salinity or tide, which could affect the rhythmic activity of the test animals. Nevertheless, the glass eels exhibited

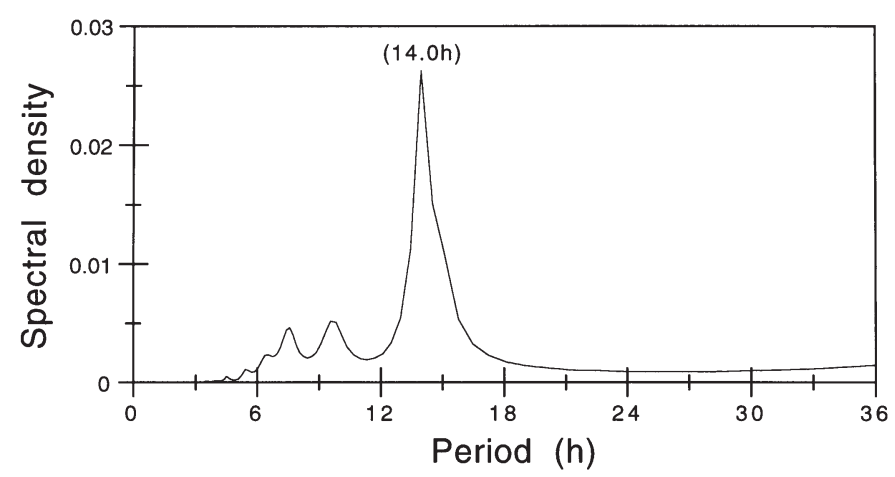

Fig. 8. Anguilla japonica. Maximum entropy spectral analysis (MESA) spectra for data presented in Fig. 5, region a. The period length $(\mathrm{h})$ corresponding to the dominant peaks in the MESA plots is given in parentheses a strong endogenous circatidal rhythm in OCR when exposed to constant conditions. The OCR rhythms were closely related to the tidal pattern at the collection site in the estuary, as the peaks in the experiments were similar to natural tides. However, unequal semidiurnal amplitudes lagged by up to $3 \mathrm{~h}$ behind the actual times of high and low tides in the field. The collection site, the Kanghwa estuary on the western coast of Korea, has a very strong tidal movement, with a maximum tidal range of $9 \mathrm{~m}$ and mixed semidiurnal $\mathrm{M}_{2}$ tides (Kantha et al. 1996, Kang et al. 1998). The physiological significance of the small OCR peaks at 7.3 and $8.3 \mathrm{~h}$ intervals in the groups of 5 glass eels cannot be immediately explained, but may have been due to group effects (Kanda \& Itazawa 1981).

Although many environmental factors (e.g. water temperature, odor, conductivity, salinity, light intensity and lunar phase) may affect the glass eels' migration, water temperature has been considered as one of the primary factors used by the eels to select continental water habitats (White \& Knights 1997, Linton et al. 2001). The experimental design in the present study focused on the effect of temperature changes on glass eels' respiration. The glass eels may experience tidal effects $(12.4 \mathrm{~h})$ in estuaries and diurnal environmental changes (24 h) after moving into rivers. The glass eels' OCR in the present study paralleled a gradually increasing temperature in the experimental chamber $\left(\Delta t=1^{\circ} \mathrm{C}\right.$ per 12 or $24 \mathrm{~h}$ ). The observed water temperature increases $\left(\Delta t=1^{\circ} \mathrm{C}\right)$ significantly affected the rhythmicity of OCR in the glass eels. Although it is difficult to directly compare natural and experimental conditions, glass eels are known to be very sensitive to temperature difference of even $1^{\circ} \mathrm{C}$ (Lee \& Kim 2001).

The glass eels, which were exposured to temperature changes over 12 and $24 \mathrm{~h}$ cycles, have different long-term trends in OCR (Figs. 3 \& 5). The reason for this difference was not pursed in this study, although it was assumed to be due to the response to the rate of change in temperature (Langford 1990). Therefore, more work is needed to elucidate the respiratory adaptation on the rate of change in temperature. The mean OCRs were apparently different at the beginning of the experiments at the same temperature of $15^{\circ} \mathrm{C}$ (Figs. 1, 3 \& 5). Even though the observed mean OCRs are different among experiments, we considered that the differences are not significant because the 95\% confidence intervals overlapped (data not shown).

The present study shows that the endogenous physiological rhythms of glass eels migrating from the open ocean to continental waters can be deduced based on 
their sensitivity to experimental water temperature changes of $1^{\circ} \mathrm{C}$ over 12 and $24 \mathrm{~h}$ periods. Anguilla japonica leptocephali hatch in the open ocean, carry out diurnal vertical migration while drifting with ocean currents toward continental habitats, and undergo metamorphosis during their migration in the open ocean. Leptocephali, therefore, are subjected to changes in water temperature that are greater than $1^{\circ} \mathrm{C}$ (Kajihara et al. 1988, Otake et al. 1998). Being subjected to such changes every $24 \mathrm{~h}$ probably affects exogenous physiological rhythms significantly. The possibility of such an assumption is supported by well-defined daily growth increments in leptocephali otoliths (Umezawa et al. 1989, Martin 1995, Tsukamoto et al. 1998, Arai et al. 2000, Shiao et al. 2001).

When the glass eels reach an estuary, they are faced with drastic environmental changes, including exposure to a strong $12.4 \mathrm{~h}$ tidal periodicity, which is in contrast to the $24 \mathrm{~h}$ vertical diurnal migration that they underwent in the open ocean. When glass eels were collected from estuaries with strong tides and subjected to experiments in the absence of external stimuli (e.g. water temperature, light, tidal action), their endogenous OCR rhythm displayed a $12.4 \mathrm{~h}$ circatidal rhythm. These results indicate that the glass eels in the estuaries were already becoming accustomed to an estuary circatidal rhythm and were adapting from their open-ocean circadian rhythm.

Although the glass eels initially exhibited a $12 \mathrm{~h}$ periodic OCR when exposed to a periodic $12 \mathrm{~h}$ temperature change, during repeat experiments a $24 \mathrm{~h}$ rhythm was observed. Such results are probably due to the glass eels' immediate exposure to experimental conditions after being collected from estuaries, where they were not only accustomed to circatidal rhythms, but also still retained some circadian rhythms. The eels' residual circadian rhythms then weakened with time. This assumption is supported by an experiment where glass eels were kept in dark BOD incubators for about $35 \mathrm{~d}$, after which they were exposed to a water temperature change every $14 \mathrm{~h}$; a period that differs from both circatidal and circadian rhythms. However, experimental results in which glass eels show sensitive responses towards 12 and $24 \mathrm{~h}$ periodic exposures to water temperature might be suspect if the eels have been recently collected from estuaries and are already attuned to $12.4 \mathrm{~h}$ circatidal and $24 \mathrm{~h}$ circadian rhythms. Such eels might have the rhythms coded into their physiological responses, in which case the experiment only exposes the internally coded rhythms by externalizing the physiological rhythmicity through a periodic temperature stimulus. Therefore, in the present study, the experiment with a $14 \mathrm{~h}$ exposure period, which is not a common divisor of 12 or $24 \mathrm{~h}$ (e.g. 3, 4, 6, 12, $24 \mathrm{~h}$ ), was deliberately chosen to study the glass eels' OCR rhythmicity. The external environmental stimulus of exposure to a $14 \mathrm{~h}$ 'Zeitgeber' of periodic water temperature changes $\left(1^{\circ} \mathrm{C} 14 \mathrm{~h}^{-1}\right)$ delivered a clear OCR response. This response corresponded to a $14 \mathrm{~h}$ periodicity, suggesting that changes as small as $1^{\circ} \mathrm{C}$ in the surrounding environment may significantly affect endogenous physiological rhythms. The results of the present study show that the glass eels' OCR coincided exactly with the experimental exposure conditions $\left(1^{\circ} \mathrm{C} 14 \mathrm{~h}^{-1}\right)$, suggesting that environmental stimuli such as small temperature variations can significantly affect the physiology of glass eels.

These data suggest that glass eels are sensitive to temperature during upstream migration, whereby the initiation of upstream locomotion would have specific temperature thresholds within the range normally encountered in the estuary. Small temperature differences of estuary waters during the upstream migration season affected the occurrence of glass eels and subsequently the size of the catch (Lee et al. 2001). The ability of glass eels to respond precisely to environmental changes in estuaries may help them find a suitable habitat for their growth in continental waters.

Acknowledgements. We thank Mrs. M. J. Lee for her helpful comments on an earlier draft of this manuscript. This study was supported in part by the Ministry of Science and Technology (MOST) of Korea under a project of the National Research Laboratory project (2000-N-NL-01-C-11) directed by W.S.K., and by a Korea Maritime Institute grant to T.W.L. (No. 20000137).

\section{LITERATURE CITED}

Arai T, Limbong D, Otake T, Tsukamoto K (2000) Validation of otolith daily increments in the tropical eel Anguilla celebesensis. Can J Zool 78:1078-1084

Bünning W (1977) Die physiologische Uhr. Springer-Verlag, Berlin

Dowse HB, Ringo JM (1989) The search for hidden periodicities in biological time series revisited. J Theor Biol 139: 487-515

Enright JT (1975) Orientation in time: endogenous clocks. In: Kinne O (ed) Marine ecology, Vol 2. John Wiley \& Sons, London, p 917-944

Gibson RN (1984) Hydrostatic pressure and the rhythmic behaviour of intertidal marine fishes. Trans Am Fish Soc 113:479-483

Gibson RN (1992) Tidally-synchronized behaviour in marine fishes. In: Ali MA (ed) Rhythms in fishes. Plenum Press, New York, p 63-81

Kajihara T, Tsukamoto K, Otake T, Mochioka N, Hasumoto H, Oya M, Tabeta O (1988) Sampling leptocephali with reference to the vertical migration and the gears. Nippon Suisan Gakkaishi 54:941-946

Kanda T, Itazawa Y (1981) Group effect on oxygen consumption and growth of the catfish eel. Bull Jpn Soc Sci Fish 47: 341-345

Kang SK, Lee SR, Lie HJ (1998) Fine grid tidal modeling of the Yellow and East China Sea. Cont Shelf Res 18:739-772

Kantha LI, Bang I, Choi JK, Suk MS (1996) Shallow water 
tides in the seas around Korea. J Korea Soc Oceanogr 31: 123-133

Kim WS, Jeon JK, Lee SH, Huh HT (1996) Effects of pentachlorophenol (PCP) on the oxygen consumption rate of the river puffer fish Takifugu obscurus. Mar Ecol Prog Ser 143:9-14

Kim WS, Huh HT, Lee JH, Rumohr H, Koh CH (1999) Endogenous circatidal rhythm in the Manila clam Ruditapes philippinarum (Bivalvia: Veneridae). Mar Biol 134:107-112

Kim WS, Huh SH, Huh HT, Lee TW (2001) Effect of salinity on endogenous rhythm of the Manila clam Ruditapes philippinarum (Bivalvia: Veneridae). Mar Biol 138:157-162

Langford TEL (1990) Ecological effects of thermal discharges. Elsevier Applied Science, London

Leatherland F, Fabridge KJ, Boujard T (1992) Lunar and semilunar rhythms in fishes. In: Ali MA (ed) Rhythms in fishes. Plenum Press, New York, p 83-107

Lee TW, Kim WS (2001) Thermal effects on respiratory activities of glass eels at different developmental stages. J Taiwan Fish Res 9:129-136

Lee TW, Hwang SD, Kim WS, Park CW (2001) Optimal temperature range of glass eels. In: Aida $\mathrm{K}$, Tsukamoto $\mathrm{K}$, Yamauchi K (eds) Proc Int Symp Adv Eel Biol, September 2001. University of Tokyo, Tokyo, p 180-182

Linton ED, Jónsson B, Noakes DLG (2001) Effects of water temperature on the upstream movement of glass eels (Anguilla sp.) in Iceland. In: Aida K, Tsukamoto K, Yamauchi K (eds) Proc Int Symp Adv Eel Biol, September 2001. University of Tokyo, Tokyo, p 234-236

Martin MH (1995) Validation of daily increments in otoliths of Anguilla rostrata (Lesueur) elvers. Can J Zool 73:208-211

Editorial responsibility: Otto Kinne (Editor),

Oldendorf/Luhe, Germany
Northcott SJ, Gibson RN, Morgan E (1990) The persistence and modulation of endogenous circatidal rhythmicity in Lipophrys pholis (Teleostei). J Mar Biol Assoc UK 70: 815-827

Northcott SJ, Gibson RN, Morgan E (1991) The effect of tidal cycles of hydrostatic pressure on the activity of Lipophrys pholis (L.) (Teleostei). J Exp Mar Biol Ecol 148:35-45

Otake T, Inakaki T, Hasumoto H, Mochioka N, Tsukamoto K (1998) Diel vertical distribution of Anguilla japonica leptocephali. Ichthyol Res 45:208-211

Palmer JD (1995) The biological rhythms and clocks of intertidal animals. Oxford University Press, Oxford

Shiao JC, Tzeng WN, Collins A, Jellyman DJ (2001) Dispersal pattern of glass eel stage of Anguilla australis revealed by otolith growth increments. Mar Ecol Prog Ser 219:241-250

Taylor MH (1984) Lunar syncronization of fish reproduction. Trans Am Fish Soc 113:484-493

Tsukamoto K (1992) Discovery of the spawning area for Japanese eel. Nature 356:789-791

Tsukamoto K, Lee TW, Mochioka N (1998) Synchronized spawning of Anguilla japonica inferred from the daily otolith increments in leptocephali. Ichthyol Res 45:187-193

Umezawa A, Tsukamoto K, Tabeta O, Yamakawa H (1989) Daily growth increments in the larval otolith of the Japanese eel Anguilla japonica. Jpn J Ichthyol 35:440-444

White EM, Knights B (1997) Environmental factors affecting migration of the European eels in the Rivers Severn and Avon, England. J Fish Biol 50:1104-1116

Wippelhauser GS, McCleave JD (1988) Rhythmic activity of migrating juvenile American eels Anguilla rostrata. J Mar Biol UK 68:81-91

Submitted: December 14, 2001; Accepted: July 4, 2002 Proofs received from author(s): October 23, 2002 